\title{
The management consulting industry in South Africa - A strategic assessment
}

\author{
H. Oosthuizen* \\ Graduate School of Business, University of Stellenbosch, \\ PO Box 610, Bellville 7535, Republic of South Africa \\ ho2@usb.sun.ac.za
}

Received September 2003

\begin{abstract}
The Management Consulting Industry (MCI) is considered to be one of the most powerful forces shaping organisational strategy. However, from its major growth phase during the late 1980s into the 1990s, and until the present time, it now appears that the industry is in a mature consolidation phase. Perhaps even an early decline. The scope and nature of the MCI is global and, consequently, the South African industry is inextricably linked to and integrated with global developments. The local industry is large in absolute terms and high in value-adding propensity. Vertical integration is limited and little advantage appears to be taken of economics of scale. The industry moves in tandem with well established international driving forces and no inflection point is expected. Nevertheless, it is considered to be under severe competitive pressures which impose a dampening effect on the overall level of industry profitability. The competitive positions and profile of rival business strategic approaches display a degree of comparability in strategic typologies. Thus, the challenge for the 'winners' in the MCI will be to differentiate themselves for both strategic and marketing positioning and even to consider redefining the business model in this turbulent and fragmented industry.
\end{abstract}

This article is based upon a research project by Kim M. Kirsten, An investigation into the industry attractiveness of the management consulting industry in South Africa, submitted in 2002 to the University of Stellenbosch Business School in partial fulfilment for the MBA degree. It was awarded a distinction

*To whom all correspondence should be addressed.

\section{Introduction}

The New Economy has transformed the world of business on a global scale and organisations are being forced to reinvent their activities. Flexibility, innovation and speed have become key business priorities for survival (Butcher, 2000:24). When a storm hits, the natural instinct is to retrench until the outlook improves, but in business, an economic storm challenges organisations not only to simply weather the downturn, but also to emerge stronger. With this in mind, management consultants play an important role in exploring new business basics that provide organisations with survival tips for today and a blueprint for tomorrow's growth.

The global management consulting industry (MCI) has, for many years, played an important role in crafting the strategies of most of the top organisations in the world. The insightful information gained from bringing in an external management consultant was considered valuable and therefore very expensive. This allowed the global MCI industry to develop into an extremely lucrative and highly sought-after professional body. In an era characterised by the rapid succession of new management concepts claiming to be the holy grail of competitive performance, management consultancy enjoyed unprecedented demand in the market of ideas (Roodt, 1997:32). Indeed, it is one of the most powerful forces shaping organisational strategy (Ryan, 1997:34).

However, from its major growth phase during the late 1980s into the 1990s, and until the present time, it appears that the MCI has been negatively affected by global economic factors (recession, globalisation, technology, terrorism) over the last few years. It is now considered to be in a period of major consolidation, both from the clients' and consultants' perspectives. This global situation has been increasingly evident in South Africa and is forcing consulting firms to relook the way they do their business. It is consequently the aim of this paper to:

\section{Analyse the South Africa MCI,}

2. Profile the current and expected strategies of rival South African consulting firms, and

3. Make strategic recommendations to the local MCI.

\section{Delimitation and plan of paper}

Within the field of strategic management, two major theoretical traditions have developed around the attempt to explain the basis for competitive advantage and thus to achieve above-average output performance. Firstly, the classic Industrial Economics-Based theory (also known as 
the Positioning-Based View) which look outside the organisation for strategic direction (Porter,1985). Here, the key determinants of strategy relate to the external characteristics of the industry in which an organisation competes. The second tradition, the Resource-Based View (Barney, 1991) looks inside the organisation and maintains that sustainable competitive advantage can only accrue to an organisation which has a resource(s) that is valuable. Today, it is well recognised that an integration of the two views is probably most appropriate (Juga, 1999).

The internal issues relating to strategy formulation by South African consulting organisations has already been addressed by Allnutt (1991), Goliath (2000), Miller (1992) and Naidoo (1996). No research, to date, has investigated the external perspective, which constitutes the focus of this research.

After outlining the research methodology, it is the plan of this paper to describe the development of the MCI, followed by an analysis of the characteristics and competitive structure, as well as competitive rivalry in the South African MCI. A summary of the major findings is next presented. Finally, conclusions are reached and recommendations made regarding strategic challenges facing the industry in South Africa.

\section{Research methodology}

The methodology that has been used in this research is a combination of primary and secondary research. Because the concept of 'industry' implies both a demand and supply side, the primary research embraced research amongst clients (demand) as well as consulting firms (supply). The primary research relating to clients was conducted on a survey basis amongst key decision makers and across industries during March-April 2002. A purposive or judgemental sampling technique was used to identify a group of respondents who were subsequently interviewed. Respondents were exclusively senior management, although at varying levels of seniority (chief executive, director, senior manager). In order to qualify for inclusion in the sample the respondents had to have been recently involved in projects where consultants were brought in, and thus had experiences with consultants on which to base their comments. The range of client industries included retail (dairy, clothing, groceries), information technology (logistics, computer supplies), insurance, telecommunications and advertising. The personal interviews, which were tape recorded, constituted a semistructured format and were in-depth discussions based on a discussion-guide.

The second component of the primary research specifically profiled the current business strategies of leading South African management consulting firms, i.e. the supply side of the industry. 'Leading firms' were determined by revenue and size and were found to include all of the global consulting firms which are active in South Africa. A questionnaire was sent (via e-mail) to a senior director or partner during February-March 2002, and returned either by e-mail or by fax.
Secondary research data were obtained by conducting a literature review of the global and local management consulting industries. This review provided the groundwork for the primary research and facilitated in understanding the present scope, strengths and limitations of the industry. It, however, emerged that very little exists in the area of theoretical concepts and standards on the management consulting industry. Academics have indeed lamented on a marked lack of theoretical explanation for the analysis of consultants and their activities (Simon \& Kumar, 2001:363).

\section{Development of the management consulting industry}

The roots of management consulting date back to the early 1900 s. At the time it had a strong engineering orientation and independent organisations used consultants and their methodologies to problem solving in many different ways (Greiner \& Metzger, 1983:9-10).

By the early 1930s firms such as Booz and Hamilton and McKinsey \& Co had been founded. General management tended to be the most dominant consulting service, and specialists such as accountants came to realise their prime position to provide advisory services, especially in financial matters (Allnutt, 1991:3-4; Naidoo, 1996:4-5).

Industry became more complex prior to World War 2 and thus a broader overview were needed. At this stage human relations emerged as a trend in consultancy. The post war years also witnessed the emergence of consultants is such areas as purchasing, traffic, production control, personnel administration, systems and procedures, budgets, public relations and marketing.

Greiner and Metzger (1983:10) assert that, by the 1950s, consultants were promted to use new and sophisticated techniques, such as capital budgeting, market research and data processing, due to the advent of computers and management science. Nevertheless, it was not until the 1960s and 1970s that management consulting as an industry started to gain recognition and to grow, albeit in an unspectacular way. During the 1980s, however, three factors stated to change this somewhat staid industry namely, information technology, globalisation and outsourcing. These factors were together responsible for the phenomenal growth of the industry during the 1990s. The entire nature and contents of consultancy changed, and this turbulence in itself presented a continued uncertainty and unpredictability about the future of the industry (Czerniawska, 1999:5).

Growing criticisms at this time further exacerbated a shift toward the consulting industry being considered 'less attractive'. These criticisms focused predominantly on the issues of high cost, questionable objectivity, hindrance to clients, inability to produce significant and meaningful results, lack of interpretation of results, and thus the questionable issue of value for money (Schaffer, 1997: xiii, 26; Shapiro, Eccles \& Soske, 1993:89; Roodt, 1997:34; Welch, 2001:305; Ashford, 1998:38; Bloch, 1999:118; Micklethwait \& Wooldridge, 1997:37). 
Turbulence in the industry, together with the rising levels of criticism, resulted in a slowdown of the industry following the massive growth phase in the 1990s. Unfortunately, very little published evidence exists to indicate and verify this slowdown and figures reported by the Management Consultancies Association (MCA) in the United Kingdom (UK), provides a rare statistical glimpse of this nature (Taylor, 2001:457-458). Currently the global MCI is considered to be in a mature phase of the life cycle. It seems to have lost much of the gloss and glamour that was associated with consulting during the boom phase of the late 1980s and during the 1990s.

The scope and nature of the MCI is global with most large multinational firms having a presence in many countries around the world, including South Africa. Consequently, the local MCI is inextricably linked to and integrated with global developments. Furthermore, the boom years were accentuated locally with the onset of intense privatisation in the late 1980s and early 1990s. Insecurity, prior to the 1994 elections, also brought an increasing amount of work to consulting firms (Allnutt, 1991:7-8).

The post-election period resulted in an even greater demand for the services of consultants from around the world. The opening of the South African economy namely exposed many South African businesses to international standards for the first time. Consequently, organisations embraced this shake up in competitive conditions with unprecedented zeal, and recruited consultants to tackle these post-election issues (Ryan, 1997:34). The presence of consultants in South Africa by the late 1990s was so widespread, it was hard to find a major organisation without a consulting team somewhere in the organisation (Ryan, 1997:34). Unfortunately, however, the public sector was being criticised for having an expensive over-reliance an consultants (Roodt, 1997:34).

Against the foregoing historical background, and recognising the close association between the global and South African MCIs, the next section explores the current as well as expected characteristics and competitive structure of the South African MCI.

\section{Characteristics and competitive structure of the south african management consulting industry}

An analysis of the characteristics and competitive structure of an industry entails examining the external context within which supplier-organisations operate and include its dominant economic features, the driving forces of industry change and the intensity of the competitive context. This analysis provides a way of thinking strategically about the industry and drawing a conclusion about whether the industry fundamentally represents an attractive investment or not (Thompson \& Strickland, 2003:76). Firstly, however, it is imperative to clearly define what is meant by the management consulting industry.

\section{The $\mathrm{MCl}$ defined}

A broad working definition of the word 'industry' is considered to be 'a group of firms whose products have so many of the same attributes that they compete for the same buyers' (Thompson \& Strickland, 2003:77). The MCI in particular may be defined as: 'The provision of objective and independent advice by qualified persons to people or clients with management responsibilities in order to help them identify and analyse management problems or opportunities' (Kehayas, 2001:43: Barcus \& Wilkenson, 1995:1-4). The components of the basic definition of industry is clearly evident, i.e.:

Group of firms:

Represented by professionally qualified persons.

Product with same attributes:

Advice concerning management activities.

Same buyers:

People with management responsibilities.

Notwithstanding the above guidelines, a "pure" definition of the consulting industry is very difficult to arrive at. This research primarily concerns the key traditional management consulting firms such as Accenture, McKinsey \& Co., Bain \& Co., PricewaterhouseCoopers Management Consulting Services, as well as the small to medium firms that have grown and developed into competitive players to the large multinationals. Several large reputable information technology (IT) consultants in South Africa, such as IBM and Computer Sciences Corporation (CSC), have also been included in the competitive mind set. The reason for this being that some traditional consulting firm's (such as Accenture and Bain) are also found to include IT consulting as one of their key service offerings.

\section{Dominant economic features}

The dominant economic features to consider in profiling the MCI are the following: market size, market growth rate and position in the industry life cycle, extent of backward and/or forward integration, economics of scale and/or learning and experience effects, as well as clustering in a particular location.

\section{Market size}

The global size of the consulting industry market is large and has been estimated at approximately US \$90-100 billion (Romocki, 2002; Benfield, 2002). However, when compared with manufacturing, mining, communications, transport and financial services, it would be considered small in global terms (Knight, 2002; Conradie, 2002). Despite being a relatively small industry in this context, it is a high valueadding industry when related to gross domestic product (Knight, 2002).

The South African consulting market was estimated to be worth about R1 billion in 1997 (Ryan, 1997:34). Unfortunately, no contemporary figures exist. Although the market is considered to have exploded in the last eight or nine years, possibly starting even sooner (Neethling, 2002), it remains small, similar to the global industry, in the 
context of larger industries (Gous, 2002; Andersen, 2002; Curry, 2002).

\section{Market growth rate and industry life cycle}

Over the last decade the worldwide MCI has grown at twice the rate of the world economy (Kumar, Simon \& Kimberley, 2000:24), making it one of the fastest growing professional areas in the global economy (Biech, 1999:3). However, today the growth rate has slowed down and the MCI is considered to be in the mature phase of the life cycle (Romocki, 2002).

In 1997 it was estimated that the South African MCI had been experiencing an annual growth rate of between 25 to 30 percent (Ryan, 1997:34). Currently, in sympathy with global trends, it has slowed down and is even perceived to be declining (Andersen, 2002 and Du Preez, 2002), mainly as a result of the downswing of the economy, an oversupply of consultants as well as the apparent impact of the fact that consulting firms are being asked to be more accountable (Neethling, 2002).

\section{Backward and forward integration}

The global consulting market is integrating forwards, backward and also collaborating in various ways. Competitors are co-operating, vendors are consulting, consultants are selling products - all of this driven by the constant pressure to achieve revenue streams (Kehayas, 2001:43).

Forward integration is evidenced by the large, global consultancies, who have received their own start-up from a lower level such as audit and tax software development, and then by forward integrating (acquiring an equity stake) into consulting per se and/or IT consulting specifically. Bain and Accenture have reportedly done this, although the results of this kind of exchange arrangement are not yet clear (Romocki, 2002). Backward integration appear, for example, when consulting firms move into software companies (Brewis, 2002), in a way 'providing the product to solve the solution' (Christodoulou, 2002). Thus, although there is integration in the MCI, it is considered harder to implement effectively compared to, say, the manufacturing industry, and furthermore carries the loaded ethical consideration of objectivity. For example, when a consulting firm integrates backward with a particular software supplier, how can the firm still be considered as objective in the strategic recommendations or proposals it makes to a client?

In South Africa there has been evidence of some vertical integration and it is expected to increase especially in the telecommunications, media and IT industries. Black empowerment partnerships have also been happening, largely to position some of the established consulting players more credibly in the present South African environment.

\section{Economics of scale and learning and experience effects}

The consulting industry is not about economies of scale (Neethling, 2002; Gouws, 2002) and whilst it is characterised by strong learning and experience effects, respondants did not consider unit costs to decline as cumulative output grows. The key resource being intellectual capital which, it is claimed, is costed for accordingly on an individual project basis.

\section{Clustering}

Globally, the consulting industry is predominant in the United States of America and Europe, especially the UK, although most large consulting firms have offices across the globe (Brewis, 2002). Locally, the consulting industry tends to be focused in the Gauteng region as most of 'big business' head offices are located in the Johannesburg/Pretoria area. Although the MCI reflects clustering, this feature tends to be of lesser importance in a globally connected world.

\section{Summary}

The South African MCI is large in absolute and value adding terms but is also considered to be in the mature, or even decline, phase of the industry life cycle. Vertical integrating occurs but is limited in its prevalence whilst economics of scale as well as learning and experience effects appear not to constitute any significant role in the industry. Consulting firms tend to cluster but this is of lesser importance in an open, global industry.

\section{Environmental driving forces}

The equilibrium, or present state of the dominant industry economic features, can be changed in a particular direction by driving forces. These forces are trends and developments which raise or lower market demand as well as impact on the nature of industry demand. In other words, the composite outcome of such a force field analysis determine the future characteristics of the industry. The following driving forces are prevalent in the MCI: globalisation, the economic cycle, societal concerns, attitudes and lifestyles, as well as technological change.

\section{Globalisation}

Globalisation infers the increased mobility of goods, services, labour, technology and capital throughout the world. Although not a new concept, its pace has increased with the advent of new telecommunication technologies.

The MCI is very susceptible to the diffusion effects of globalisation and firstly, its size has been grown considerably because consultants were in demand to advise businesses on how to globalise successfully, using their global experiences and best practices to suit the local markets. Secondly, the uncertainty and complexity of the global market demand also compelled consulting firms to shift the emphasis of the nature of their portfolio of services 
to advise on successfully transferring components of the value chain to new geographic configurations.

During this time of global change particularly three major characteristics have converged and impact on the nature of demand for consultancy namely, (i) clients want innovative thinking, (ii) they do not want to wait years before that innovative solution has an impact and (iii) they want to set more ambitions and more tangible goals for their consultants (Czerniawska, 1999:27 \& 29).

In South Africa the effect of globalisation on the MCI was somewhat more intense than in most other countries in that local organisations were forced to respond to the new rules of globalisation suddenly rather than gradually, and at the same time had to adjust to the political transformation that was taking place, where issues such as job advancement, black advancement and sosio-political issues played a role in any consulting project (Ackerman, 2002).

\section{Economic cycle}

Globally, the state of the economy is one of the largest driving forces affecting the $\mathrm{MCI}$ and cycles in this industry have been find to closely follow a country's GDP level. During a bullish cycle, client firms tend to have 'cash to burn' and as a result consultants benefit (Romocki, 2002). When the economy is down, consulting services, along with marketing and research, is probably the first place clients tend to cut (Conradie, 2002). As a result, consultants are then considerably more driven by the concept of offering greater value for money.

Conditions in the general economy may also favour different kinds of consulting services being in demand. For example acquisitions and mergers and, during a downturn of the business cycle turnaround and efficiency-improvement strategies. This is the situation that both the global economy and the MCI (including South Africa) is currently (at time of writing) experiencing, and it is expected to continue for some time.

\section{Societal concerns, attitudes and lifestyles}

Emerging social issues and changing attitudes and lifestyles are powerful drivers of industry change. In South Africa, particularly after the 1994 elections, these factors created a large demand for the services of consultants amongst both private organisations and government sectors. Consultants were brought in to assist private companies with the development of survival strategies for the New South Africa, as they were now suddenly also exposed to international elements, including the threat of international competition for the first time. As far as the government sector is concerned, consulting firms who do not align themselves with black-owned partnership firms, could struggle to operate.

Furthermore, it was considered that the skills levels of previously disadvantaged black people are lacking, and that there are insufficient black graduates emerging from business schools to fill the necessary positions in the consulting firms. It is expected to take some time to reach the desired levels and until such time, consulting firms have to skill up their black staff at considerable expense.

Finally, shifting societal concerns, attitudes, and lifestyles alter the profile of competition, usually favouring those that can respond quickly and creatively with products and services targeted to the new trends and conditions. In South Africa it has given rise to the establishment of many, small niche-player consulting firms.

\section{Technological change}

Advances in technology, particularly Internet technology, can substantially shape an industry's environment and thus mandate changes in business strategy. The pace of technological change in the MCI is fast, with the industry growing in leaps and bounds as the technology develops and clients demand new improved, and innovative service offerings.

Consulting opportunities are associated with cutting edge technology and the industry consequently tries to anticipate what the next 'hot' trend is going to be, then 'loads up its intellectual arsenal to tackle it' (Romocki, 2002). The downside of this, however, being the often-heard entisism about consultants that they tend to pick up on concepts that have been used for years, and turn them into a 'hot new thing', generating unfounded hype and excitement amongst many clients. For this reason large consulting projects often tend to use proven technology or even offer new product introductions at reduced rates.

The development of new technologies has had a significant effect on the MCI and the challenge remains to assess how it should best be factored into strategy formulation.

\section{Summary}

The South African MCI moves in tandem with the international environmental driving forces of globalisation, the economic cycle, societal concerns, attitudes and lifestyles, as well as technological change. The composite impact of these forces is expected to continue and no major change of direction, or inflection point (Grove, 1997:32), is expected. For consulting firms the challenge remains to capture the growth opportunities and to adjust the emphasis within their portfolio of services in order to accommodate the changing nature of demand. In particular, South African consulting firms had to content with the relatively sudden onset of globalisation and, simultaneously develop survival strategies for clients due to the threat of international competition and the implications associated with political transformation. Furthermore, the economic downtown has had a dampening affect on the South African MCI.

\section{Competitive context}

The competitive context of an industry is considered to be best demonstrated by the state of the composite effect of five forces (Porter, 1980:4) namely, rivalry, potential entry of new competitors, substitute offerings, pressure stemming from supplier collaboration and bargaining power and 
pressure stemming from buyer collaboration and bargaining power.

\section{Rivalry among competing firms}

Rivalry is the strongest competitive force in the MCI, both globally and locally (Christodoulou, 2002). This stems from the competitive pressures associated with the following factors:

- Most multinational consulting firms have established offices in all major cities around the world.

- The industry is highly concentrated with the 'Big Five' (Andersen, KFMG, Ernst \& Young, Deloitte and PricewaterhouseCoopers) taking approximately 50 percent of the global market.

- $\quad$ There is an extraordinary long tail of small to medium sized consulting firms developing. This is a growing trend and renders the MCI with an oversupply of consultants and at the same time a very fragmented profile.

- $\quad$ Although many forms of communication channels are used, clients perceive very little differentiation amongst service products, thus resulting in a generic ('commodity') offering which is potentially very susceptible to price competition. The following are some comments made in this regard: 'weakly differentiated', 'essentially all the same', 'much of a muchness', 'similar approach and style', 'all quite similar' and 'using the same standard models'.

\section{Potential entry of new competitors}

The MCI is generally easy to enter with very low barriers to entry. However, it is nevertheless a difficult industry to really succeed in. There is also a growing trend for consultants to be certified by an international as well as national institute. In the latter regard the South African Institute of Management Consultants (IMCSA) was formed as long ago as 1972 to professionalise and self-regulate the industry in this country. The consultant may be struck off the role for unprofessional conduct.

New entrants to the MCI in South Africa are most often experienced consultants breaking away from the large firms, intellectual capital being very transferable. These smaller or niche firms are considered to be developing into serious competitors for the major players as they offer the following competitive advantages:

- Clients no longer necessarily look for the 'total solution', resulting in a trend away from generalisation in consulting to specialisation, which favours the smaller firm (Kubr, 2002:44-45).

- The growth of SMEs, which are generally unable to afford the services of large consulting firms, contribute to the demand for smaller consulting firms.
- $\quad$ Smaller firms can offer a more personalised (flexible) service at lower prices with an ability to deliver meaningful, actionable and implementable results $(\mathrm{Du}$ Preez, 2002).

Overall, the potential entry of new competitors may be regarded as a strong competitive force. This is expected to intensity with a growing demand for the services of smaller consulting firms.

\section{Substitute offerings}

The competitive threat from substitute offerings appear to be shifting from a weak to a moderate force. This is the result of two major trends:

- Accounting firms, law firms, marketing and research firms, even advertising firms, as well as other professional bodies are providing management consulting services as part of their mainstream service (Kumar et al., 2000:26). In this regard the Internet is a major contributing factor to the altering and the blurring of the traditional MCI boundaries.

- Substitute offerings may also emanate from clients relying on their own internal resources rather than bringing in external consultants (Kubr, 2002:50-53). This trend is continuing locally (Curry, 2002) and some of the key players in the banking industry (e.g. FirstRaed and ABSA) are currently in the process of moving their reliance away from external consultants (Kirsten, 2002:96).

\section{Pressure from supplier collaboration and bargaining power}

The bargaining power of suppliers is considered to be relatively weak (Kumar et al., 2000:26) end it is not envisaged to change substantially in the foreseeable future (Kumar et al., 2000:26).

Backward integration can further diminish any supplier power. Such direct financial links, however, may call the concept of objective advice into question. It is thus more appropriate for consulting firms to rely on less formal types of collaborations with a range of suppliers. Recommendations can consequently be made on the client's specific requirements and not possibly be biased to the consultant's 'contracted' suppliers.

\section{Pressure from buyer collaboration and bargaining power}

The bargaining power of buyers seems to be increasing (Kumar et al., 2000:26) where, particularly mega-clients are more sophisticated and increasingly demanding more from consultancy suppliers (Kumar,et al. 2000:26). There is, however, little evidence of real collaboration with buyers, although some consulting firms are prepared to take shares in the client firm as part of the remuneration package (Brewis, 2002). 
Overall, the competitive pressure resulting from buyer collaboration and bargaining power may be considered to be slowly shifting from weak to moderate.

\section{Summary}

The relative strength of the competitive forces at play in the MCI may be summarised as follows:

\section{Rivalry $\rightarrow$ Strong}

New competitors $\rightarrow$ Strong and intensifying

Substitutes $\rightarrow$ Weak to moderate

Supplier power $\rightarrow$ Weak

Buyer power $\rightarrow$ Weak to moderate

The MCI appears to be currently under two strong competitive forces (rivalry and new competitors) whilst two other forces (substitutes and buyer power) are increasing in strength. The industry may be considered as being under pressures which impose a dampening effect on overall industry profitability.

\section{Fundamental attractiveness of the management consulting industry}

A review of the dominant economic features of the South African MCI suggests a relatively large industry, albeit in the mature/early decline phase of the business cycle. This situation spawns increased rivalry and pressure on industry profitability levels, and is confirmed by the composite impact of the forces of the competitive context. No inflection point is indicated by the driving forces and consequently the fundamental attractiveness of the MCI must be considered as moving towards the realm of 'unattractive'.

Beauty, however, is in the eye of the beholder and should be appraised from the standpoint of a particular party. For the large South African consulting firms, their profitability is increasingly called into question as the exchange rate plays havoc with revenues sent back to the international parent firm, and as their overheads surge whilst demand for their services appears to be levelling off. For the smaller, niche player specialist firm, the opportunities seem to be great.

\section{Competitive rivalry in the South African management consulting industry}

Competitive rivalry has been identified as the strongest single competitive force in the South African MCI. In this section those industry key success factors that should shape a consulting firm's competitive strategy is identified, followed by an assessment of the competitive positions of rival firms as well as constructing a monitoring profile of the major players in order to predict their next moves.

\section{Industry key success factors}

Industry key success factors (IKSFs) are those considerations around which rival firms should design and execute their strategies. They are the icons which determine the ultimate long term competitive success or failure of a firm. Thus, any firm can gain competitive advantage by focussing its strategy, and being distinctly better than rivals, on one or more of these factors. In the MCI the following IKSFs may at present (IKSFs very from time to time in the same industry) be identified: image and reputation, type of people employed, intellectual capability and knowledge, delivery and implementation as well as value for money.

- Image and reputation: This factor is characterised by attributes such as an international footprint, best practices and a reputable and ethical track record.

- Type of people: The people factor relate to the concept of professionalism, i.e. 'the best', training, customer relations and boardroom confidence.

- Intellectual capability and knowledge: This factor embraces the perceived intellectual capability of people employed as well as their considered knowledge, understanding and experience of a particular client environment. From the perspective of any individual firm this is a most important resource because it represents a highly moveable or transferable skill.

- Delivery and implementation: To succeed on this factor firms must be able to deliver a quick turnaround, provide results which are actionable and followed through. This factor is particularly relevant in South Africa where there are different skills levels and huge experience gaps, and thus how the strategy is brought alive successfully, i.e. 'Making it happen'.

- Value for money: Although price per se is not considered to be an IKSF, the very high levels of consulting fees push value for money into the realm of an IKSF. Overseas consulting fees are on average US \$170-200 per hour and in South Africa R700-900 per hour.

\section{Competitive positions of rival firms}

The competitive market positions of rival firms may be determined by the construction of a Group Map. The figure below is such a map and reflects clients' perspective of the key consulting firms in the South Africa MCI. The twodimensional construct was achieved by using perceived revenues and firm size as horizontal and vertical axes respectively.

Accenture, McKinsey and Bain do not fit into any of the above groupings, and tend to occupy the space in the medium to high revenues bracket and in the medium to large size within the local market. They could, however, be viewed as close rivals as they are all multinational firms and all able to apply best practices. The differentiator appears to be that Accenture have broadened their services to include IT and other consulting, whereas Bain and McKinsey are firms that tend to focus predominantly on strategy consulting.

Perusal of the market positions of the groupings in the South African MCI suggests that: 


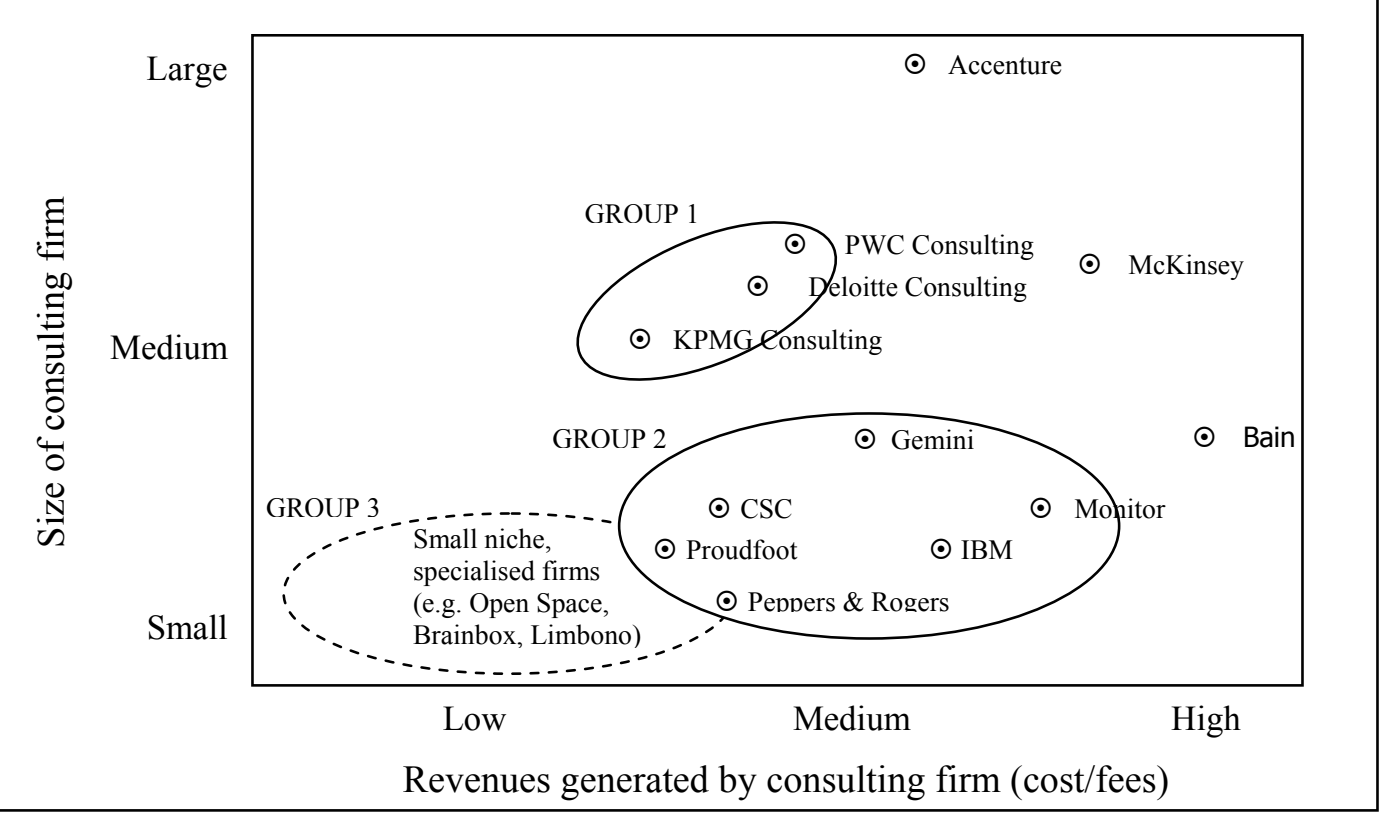

Figure 1; Strategic map of South African consulting market

- Groups 1 and 2 are in close proximity to one another, separated slightly by perception of market size, and are therefore in strong competitive rivalry. Group 3 is somewhat more apart on the Group Map and is thus perceived as persuing a distinctly different competitive approach.

- Bearing in mind the influence of the industry driving forces and the competitive context on the profit potential of the MCI, it would appear that Group 3 (small, niche, specialist firms) are relatively favoured when compared to Groups 1 and 2.

- Although three different groupings may be identified, the Group Map still tends to reflect a broad nucleus, or clustering of rival firms, rather than distinct and widely dispersed groups. This suggests the possible existence of essentially comparable or even similar strategies.

An analysis of strategic groups act as a sound basis and reference point for monitoring the evolution of an industry's competitive structure as it emerges from possible changes in the strategies of rival firms. This is discussed in the next section.

\section{Profile of rival strategies}

Anticipating the next move of a rival, particularly a possible change in strategy, is probably the most difficult part of competitor analysis. A good indication, however, may be gleamed from profiling the overall competitive posture of rival firms. The likelihood that an organisation will continue with it's present business strategy, or not, is assumed to depend on how satisfied it is with its current performance. Such a competitive posture for the South African MCI is appended (see Appendix 1), 'Profiling the objectives and strategies of leading consulting firms in South Africa', and may be summarised as follows:

- Most have a global competitive scope, with the exception of Gemini and CSC (who both follow a multi-country strategy).

- Most firms' strategic intent is to specifically be amongst the top five industry leaders, with the exceptions of Deloitte (who want to be leaders in their areas) and McKinsey (who want to be highly regarded in the market, rather than the biggest).

- Most claim to gain market share by means of expansion via internal growth, with the exceptions of Accenture (who did not respond to this question) and CSC (who expand their market share by means of acquisitions).

- Most firms feel that their competitive position is getting stronger/on the move, with the exceptions of Accenture (who feel they are well-entrenched) and Deloitte (who feel they are well established as one of the top two in the industries they operate in).

- Most firms feel their strategic posture is one of Prospector, with the exceptions of Gemini and CSC (who are both Analysers), as well as Deloitte (who did not respond to this question). The Prospector and Analyser descriptions are based on Miles and Snow, (1978) and broadly denote 'first mover' firms as Prospectors whilst Analysers tend to be 'followers'.

- All firms felt their competitive strategy in one of differentiation, based on a wide variety of attributes, 
with only Deloitte and PWC also following a high-end focus competitive strategy. It must be noted that the claim of a differentiation strategy by consulting firms is in sharp contrast to the perception of clients, who viewed competing offerings as approaching a 'generic' typology. The word 'differentiation' is used here in the sense of the generic Porter strategy (Porter, 1985: chapter 4).

It appears that rival firms tend to follow very similar competitive business strategies and that there is no clear indication in the competitive profile that significant new strategic moves could presently be contemplated by any one rival. It can thus be expected that, broadly speaking, rival firms are to continue their present business strategies with only minor fine turning.

\section{Summary}

An analysis of the competitive positions and profile of rival strategic approaches, tend to confirm a certain degree of comparability in strategic business typologies. It would consequently appear unlikely that any of the rival firms currently succeed in clearly differentiating on the basis of the industry key success factors.

\section{Summary of major findings}

The aims of this paper included an analysis of the South African MCI as well as a profiling of the current and expected strategies of consulting firms operating in the local market. The major finding's in this regard are briefly summarised below:

- $\quad$ The local MCI is inextricably linked to and integrated with global developments in this industry. For this reason, any reference to the South African MCI recognises this proviso.

- The South African MCI is large in absolute and high in value-adding terms, but it is also considered to be in the mature, or even decline, phase of the life cycle. Vertical integration does occur but is limited in its prevalence whist economies of scale as well as learning and experience effects do not appear to be considered to constitute any significant role in the industry. Consulting firms tend to cluster in the Gauteng-area although this is of lesser importance in this open and global industry.

- The South African MCI moves in tandem with the international environmental driving forces of globalisation, the economic cycle, societal concerns, attitudes and lifestyles, as well as technological change. The composite impact of these factors on the size and nature of the industry is well entrenched and is expected to continue relatively unchanged. No inflection point is foreseen in the near future.

- The South African MCI is currently experiencing two strong competitive forces (rivalry and new competitors) whilst two other forces (substitutes and buyer power) are increasing in strength. Supplier power is considered to be weak. The industry may be considered as being under severe competitive pressures which impose a dampening effect on the level of industry-wide profitability.

- Generally speaking the fundamental attractiveness of the South African MCI must be considered as shifting towards the realm of 'unattractive'.

- An analysis of the competitive positions and profile of rival business strategic approaches, confirm a degree of comparability in strategic typologies.

\section{Conclusions and recommendations}

Industry, competitive and rival analyses provide answers to the 'What' questions, i.e. they represent the gathering of information. However, in order to comprehend the meaning of the observed phenomena it is furthermore imperative to find answers to the 'So What' questions (i.e. draw conclusions) as well as the 'Now What' questions (i.e. make action recommendations regarding the challenges facing the industry). These two aspects concern the final aim set for this paper.

The following conclusions are considered to emanate from this research.

- A large and high value adding industry tends to attract the interest of new-comers, particularly the smaller firm should the industry be concentrated in a relatively few large players. This is the case in the South African MCI with small entrants being both new per $s e$, as well as spin-offs from large firms.

- A growth slowdown in an industry hightens competitive pressures and spawn increased rivalry. Firms face pressures for increased efficiencies. The foregoing appears to be the position in the South African MCI, although reservations were expressed that economies of scale and learning and experience effects could apply to this industry.

- The composite effects of the driving forces result in the following:

(i) An overall positive effect on the size (growth) of the MCI. However, this depends upon the rather dominating influence of fluctuations in the economic cycle.

(ii) A changing nature of the market in terms of 'Who buys' (e.g. a shift from large organisations and government to also include SME clients) and 'How used' (e.g. the development of new needs such as specialisation vs. generalisation). These shifts tend to favour the smaller consulting firms. As the same time, however, it presents large firm's with a window of opportunity to differentiate via their portfolio of services.

- The pressures on industry profitability imposed by the competitive forces in the MCI increases cross- 
organisation rivalry. This will challenge firms to differentiate for marketing positioning (being conceptually different to strategic positioning) and even to consider redefining the existing business model in the industry.

- The existing business model in the MCI is being challenged by two conditions:

\# It appears to be highly susceptible to the influences of deconstruction (Bresser, Hitt \& Nixon, 2000) imposed by the knowledge economy. This has already started to occur

(www.clarity-onsulting.com/deconstruction_of_it htm)

\# Substitutes are blurring the boundaries of the traditional MCI.

- $\quad$ The tendency to the strategic clustering of rival firms suggests that it is unlikely that any firm in the South African MCI really succeeds in clearly differentiating itself on the basis of the industry key success factors, which are mainly marketing related.

- $\quad$ The predominance of marketing related IKSFs in an industry that is not overtly price-sensitive, suggests the application and prioritisation of non-price competitive elements (referred to in marketing parlance as differentiation) to add value.

- Under the present and expected industry conditions in the South African MCI, the winning firms in this intensely competitive environment will be those who can differentiate themselves in the perception of the market (clients). Kirsten (2002:87) observes that: 'So, there appears to be a great deal of room for improvement regarding the differentiation issue'.

An encompassing and primary recommendation to the South African MCI appears to be that there is a need for consulting firms to 'consult themselves' regarding the marketing of their services.

Two secondary recommendations are that the:

- Possible influences of economies of scale and of learning and experience effects in the MCI be investigated, and not summarily be discarded.

- Level and nature of deconstruction in the MCI be investigated with a view to a possible new model for the industry value chain.

\section{Finally}

'Any criticism discussed in this document is not intended to cause damage to the image of the consulting industry, or to negate its overall usefulness in general business. Instead, it is discussed with a genuine desire to help consulting firms identify their own shortfalls, in order to realign themselves to better save their client's needs and to redress the serious concerns that clients have for the consulting industry' (Kirsten, 2002:159).

\section{References}

Ackerman, Raymond. 2002. Chairman, Pick 'n Pay. Cape Town, 11 April. Personal communication.

Allnutt, J.D. 1991. 'The corporate image of management consulting firms'. Unpublished Master of Business Administration Study Project. Johannesburg: University of Witwatersrand.

Andersen, Fred. 2002. Director of Commercial Services, Parmalat SA. Cape Town, 7 March. Personal communication.

Ashford, M. 1998. Con tricks. London: Simon and Schuster.

Barcus, J.W. \& Wilkinson, W. (Eds.). 1995. What is management consulting? Handbook of Management Consulting Services. Blacklick: McGraw-Hill.

Barney, J.B. 1991. 'Firm resources and sustained competitive advantage', Journal of Management, 17(1):99120.

Benfield, Nikki. 2002. Country Marketing Director, Accenture, S.A., mini-questionnaire respondent.

Biech, E. 1999. The business of consulting: The basics and beyond. San Francisco: Jossey-Bass Pfeiffer.

Bloch, B. 1999. 'How they put the "con" in consulting', Managerial Auditing Journal, 14(3):115-118.

Bresser, R.K.F., Hitt, M.A., Nixon, R.D. \& Heustel, D. (Eds.). Winning strategies in a deconstructing world. Chichester: John Wiley and Sons.

Brewis, Terry. 2002. Senior Marketing Executive, Woolworths. Cape Town, 14 March. Personal communication.

Butcher, C. 2000. 'The rise of the multi-disciplinary pro', PMR, March:24-25.

Christodoulou, Nick. 2002. Chief Executive: Business Development, Sanlam. Cape Town, 18 March. Personal communication.

Conradie, Marius. 2002. Executive Head of Strategy and Scenario Planning, Vodacom. Cape Town, 23 April. Personal communication.

Curry, Brent. 2002. Retail Systems Director, The Foschini Group. Cape Town. 15 March. Personal communication.

Czerniawska, F. 1999. Management consulting in the $21^{\text {st }}$ century. Basingstoke, Hampshire: Macmillan Press.

Du Preez, Tony. 2002. Information Systems Director, The Foschini Group. Cape Town. 15 March. Personal communication. 
Goliath, D.Q.D. 2000. 'The marketing strategies and tactics of management consulting firms'. Unpublished Master of Business Administration Study Project. Bellville: University of Stellenbosch.

Gous, Nic. 2002. Director, Universal Computer Services, Cape Town. 13 March. Personal communication.

Greiner, L.E. \& Metzger, R.O. 1983. Consulting to management. New York: Prentice-Hall.

Grove, A. 1997. Only the paranoid survive. London: Harper Collias Publishers

Hayes, I.S. The deconstruction of the IT services market. [online]

www.clarity-consulting.com/deconstruction_of_it.htm.

Juga, J. 1999. 'Generic capabilities: combining positional and resource-based views for strategic advantage', Journal of Strategic Management, 7(1) March: 3-18.

Kehayas, A. 2001. 'Wherefore the consultant?', Management Today, 7(4) May:43-44.

Kirstin, K.M. 2002. 'An investigation into the industry attractiveness of the management consulting industry in South Africa'. Unpublished Master of Business Administration Study Project. University of Stellenbosch.

Knight, Jessica. 2002. Director, Strategy and Marketing, Affinity Logic. Cape Town. 22 April. Personal communication.

Kubr, M. 2002. How to select and use consultants. $4^{\text {th }}$ Edition. Geneva: International Labour Organisation.

Kumar, V., Simon, A. \& Kimberley, N. 2000. 'Strategic capabilities which lead to management consulting success in Australia', Management Decision, 38(1):24-35.

Lewin, K. Force-field analysis. [online] www.accelteam.com/techniques/force_field_analysis.html.

Micklethwait, J. \& Wooldridge, A. 1997. The witch doctors. London: Heinemann.

Miles, R.E. \& Snow, C.C. 1978. Organisational strategy, structure and process. New York: McGraw-Hill Book Co.

Miller, P. 1992. 'Management consulting competence'. Unpublished Master of Management Study Project. Johannesburg: University of Witwatersrand.

Naidoo, K. 1996. 'Strategic adaptation and the role of management consulting firms'. Unpublished Master of Business Administration Study Project. Johannesburg: University of Witwatersrand.

Neethling, Martin. 2002. Managing Director, Berry Bush BBDO. Cape Town, 12 April. Personal communication.
Porter, M. 1980. Competitive strategy: Techniques for analyzing industries and competitors. New York: The Free Press.

Porter, M. 1985. Competitive advantage. New York: The Free Press.

Romocki, Andrew. 2002. Director, Rocanda Enterprises Ltd. Alberta, Canada, 18 April. Taped, telephonic communication.

Roodt, A. 1997. 'Management consulting: quo vadis?' Management Today, 13(7) August:32-34.

Ryan, C. 1997. 'Change now ... before you lose?', Financial Mail, 147(5): November 21:34-37.

Schaffer, R.H. 1997. High impact consulting: How clients and consultants can leverage rapid gains into long-term results. San Francisco: Jossey-Bass Publishers.

Simon, A. \& Kumar, V. 2001. 'Clients views on strategic capabilities which lead to management consulting success', Management Decisions, 39(5):362-372.

Shapiro, E.C., Eccles, R.G. \& Soske, T.L. 1993. 'Consulting: Has the solution become part of the problem?, Sloan Management Review, 8(10) Summer:89-95.

Taylor, S. 2001. 'Announcement: Slowdown in growth in the management consulting sector', Strategic Change, 8(10):457-458.

Thompson, A.A. \& Strickland, A.J. 2003. Strategic management. $13^{\text {th }}$ Edition. New York: McGraw-Hill.

Welch, J. 2001. Jack - what I've learnt leading a great company and great people. London: Headline Book Publishing. 
Appendix 1: Profiling the objectives and strategies of leading consulting firms in South Africa

\begin{tabular}{|c|c|c|c|c|c|c|}
\hline $\begin{array}{c}\text { Management } \\
\text { Consulting Firm } \\
\end{array}$ & $\begin{array}{c}\begin{array}{c}\text { Competitive } \\
\text { Scope }\end{array} \\
\end{array}$ & Strategic Intent & $\begin{array}{c}\text { Market Share } \\
\text { Objective }\end{array}$ & $\begin{array}{c}\text { Competitive } \\
\text { Position/Situation } \\
\end{array}$ & $\begin{array}{l}\text { Strategic } \\
\text { Posture }\end{array}$ & $\begin{array}{c}\text { Competitive } \\
\text { Strategy } \\
\end{array}$ \\
\hline Accenture & Global & $\begin{array}{l}\text { Maintain leader } \\
\text { position }\end{array}$ & Not answered & $\begin{array}{l}\text { Well entrenched/able } \\
\text { to maintain present } \\
\text { position }\end{array}$ & Prospector & $\begin{array}{l}\text { Pursuing } \\
\text { differentiation based } \\
\text { on: quality, service, } \\
\text { technological } \\
\text { superiority, breadth } \\
\text { of product line, } \\
\text { image and reputation, } \\
\text { cost effective/more } \\
\text { value for money }\end{array}$ \\
\hline $\begin{array}{l}\text { Bain and } \\
\text { Company }\end{array}$ & Global & $\begin{array}{l}\text { Overtake the } \\
\text { present industry } \\
\text { leader }\end{array}$ & $\begin{array}{l}\text { Expansion via internal } \\
\text { growth }\end{array}$ & $\begin{array}{l}\text { Getting stronger/on } \\
\text { the move }\end{array}$ & Prospector & $\begin{array}{l}\text { Pursuing } \\
\text { differentiation based } \\
\text { on: quality, image } \\
\text { and reputation }\end{array}$ \\
\hline $\begin{array}{l}\text { Computer } \\
\text { Sciences } \\
\text { Corporation } \\
\text { (CSC) }\end{array}$ & Multi-country & $\begin{array}{l}\text { Be among top } \\
\text { five industry } \\
\text { leaders }\end{array}$ & $\begin{array}{l}\text { Aggressive expansion } \\
\text { via both acquisition } \\
\text { and/or internal growth }\end{array}$ & $\begin{array}{l}\text { Getting stronger/on } \\
\text { the move }\end{array}$ & Analyser & $\begin{array}{l}\text { Pursuing } \\
\text { differentiation based } \\
\text { on: technological } \\
\text { superiority, image } \\
\text { and reputation }\end{array}$ \\
\hline $\begin{array}{l}\text { Deloitte } \\
\text { Consulting }\end{array}$ & Global & $\begin{array}{l}\text { To be the leading } \\
\text { consulting firm } \\
\text { in the industries } \\
\text { and specific } \\
\text { areas where we } \\
\text { focus }\end{array}$ & $\begin{array}{l}\text { Expansion via internal } \\
\text { growth }\end{array}$ & $\begin{array}{l}\text { Well established as } \\
\text { one of the top two } \\
\text { consulting firms in } \\
\text { SA in certain } \\
\text { industries } \\
\text { (Manufacturing, } \\
\text { Public Sector, Energy, } \\
\text { Utilities) and growing } \\
\text { in Communication. } \\
\text { The leading large } \\
\text { ERP implementation } \\
\text { firm with strong } \\
\text { capabilities in } \\
\text { Operations and } \\
\text { Change Leadership }\end{array}$ & $\begin{array}{l}\text { A firm who builds } \\
\text { and maintains long- } \\
\text { term relations with } \\
\text { selected clients. We } \\
\text { grow our business by } \\
\text { delivering ongoing } \\
\text { value to our clients. } \\
\text { This requires } \\
\text { continued innovation } \\
\text { in terms of products } \\
\text { and services, } \\
\text { flexibility and agility } \\
\text { to grow and expand } \\
\text { as our clients grow } \\
\text { and globalise their } \\
\text { business }\end{array}$ & $\begin{array}{l}\text { Focusing on a narrow } \\
\text { market niche: the } \\
\text { high end market and } \\
\text { Pursuing } \\
\text { differentiation based } \\
\text { on: quality, service, } \\
\text { image and reputation, } \\
\text { thought leadership, } \\
\text { innovation, client } \\
\text { partnerships, client } \\
\text { collaborations, } \\
\text { authentic consultants }\end{array}$ \\
\hline $\begin{array}{l}\text { Gemini } \\
\text { Consulting }\end{array}$ & Multi-country & $\begin{array}{l}\text { Be among top } \\
\text { five industry } \\
\text { leaders and } \\
\text { Leadership in } \\
\text { chosen markets } \\
\text { and offerings }\end{array}$ & $\begin{array}{l}\text { Expansion via internal } \\
\text { growth and Alliances } \\
\text { with associated } \\
\text { businesses that are } \\
\text { non- competitive, e.g. } \\
\text { IT businesses }\end{array}$ & $\begin{array}{l}\text { Getting stronger/on } \\
\text { the move }\end{array}$ & $\begin{array}{l}\text { Analyser (but not } \\
\text { low cost offerings by } \\
\text { copying/improving } \\
\text { prospectors product, } \\
\text { rather improving and } \\
\text { customising own } \\
\text { offerings) }\end{array}$ & $\begin{array}{l}\text { Pursuing } \\
\text { differentiation based } \\
\text { on: quality, image } \\
\text { and reputation, } \\
\text { methodology }\end{array}$ \\
\hline IBM & Global & $\begin{array}{l}\text { Be among the } \\
\text { top five industry } \\
\text { leaders }\end{array}$ & $\begin{array}{l}\text { Aggressive expansion } \\
\text { via both acquisition } \\
\text { and/or internal growth }\end{array}$ & $\begin{array}{l}\text { Going after a different } \\
\text { market position, } \\
\text { trying to move from a } \\
\text { weaker to a stronger } \\
\text { position }\end{array}$ & Analyser & $\begin{array}{l}\text { Pursuing } \\
\text { differentiation based } \\
\text { on: breadth of } \\
\text { product line }\end{array}$ \\
\hline $\begin{array}{l}\text { McKinsey and } \\
\text { Company }\end{array}$ & Global & $\begin{array}{l}\text { To be the most } \\
\text { highly regarded, } \\
\text { as opposed to } \\
\text { being the } \\
\text { biggest. Pre- } \\
\text { eminence (vs. } \\
\text { dominance, like } \\
\text { Accenture) }\end{array}$ & $\begin{array}{l}\text { Expansion via internal } \\
\text { growth - organic } \\
\text { growth track }\end{array}$ & $\begin{array}{l}\text { Well-entrenched, able } \\
\text { to maintain its present } \\
\text { position - there's } \\
\text { definite growth } \\
\text { potential, although } \\
\text { maybe not } \\
\text { extraordinary growth. } \\
\text { To be well established } \\
\text { as one of the top two } \\
\text { in certain industries }\end{array}$ & Prospector & $\begin{array}{l}\text { Pursuing } \\
\text { differentiation based } \\
\text { on: Impact, value for } \\
\text { money, high quality } \\
\text { work, reputation. A } \\
\text { team gets measured } \\
\text { on impact of the } \\
\text { project - sustainable } \\
\text { performance } \\
\text { improvement }\end{array}$ \\
\hline $\begin{array}{l}\text { Pricewaterhouse } \\
\text { Coopers (PwC) } \\
\text { Management } \\
\text { Consulting } \\
\text { Services }\end{array}$ & Global & $\begin{array}{l}\text { Be among the } \\
\text { top five industry } \\
\text { leaders }\end{array}$ & $\begin{array}{l}\text { Expansion via } \\
\text { Internal growth }\end{array}$ & $\begin{array}{l}\text { Getting stronger/on } \\
\text { the move }\end{array}$ & Prospector & $\begin{array}{l}\text { Focusing on a narrow } \\
\text { market niche: the } \\
\text { high end market and } \\
\text { Pursuing } \\
\text { differentiation based } \\
\text { on: breadth of } \\
\text { product line }\end{array}$ \\
\hline
\end{tabular}

